\title{
Anaphylatoxin C5a-induced toll-like receptor 4 signaling in bovine neutrophils
}

\author{
M. G. H. Stevens, ${ }^{\star}$ M. Van Poucke,† L. J. Peelman,† P. Rainard,‡ B. De Spiegeleer,§ C. Rogiers, ${ }^{\star}$ \\ G. R. Van de Walle, ${ }^{\star}$ L. Duchateau, ${ }^{*}$ and C. Burvenich ${ }^{\star 1}$ \\ *Department of Comparative Physiology and Biometrics, and \\ †Department of Nutrition, Genetics and Ethology, Faculty of Veterinary Medicine, Ghent University, 9820 Merelbeke, Belgium \\ fINRA, UR1282, Laboratoire d'Infectiologie Animale et Santé Publique, 37380 Nouzilly, France \\ §Drug Quality and Registration (DruQuaR) group, Faculty of Pharmaceutical Sciences, Ghent University, B-9000 Ghent, Belgium
}

\begin{abstract}
It is well known that signaling in neutrophils through both the complement component $5 \mathrm{a}$ (C5a) and C5a receptor (C5aR) and the toll-like receptor 4 (TLR4) pathways plays an essential role in innate defense. Neutrophil dysfunction, as seen during sepsis in severe mastitis during the periparturient period, is correlated with elevated concentrations of anaphylatoxin C5a. The aim of the current study was to elucidate the effect of C5a on TLR4 signaling in bovine neutrophils. Neutrophils were incubated with a high (but physiological) dose of purified C5a, and mRNA was extracted from neutrophils at different time points postincubation (PI). The incubation with C5a resulted in a biphasic C5aR expression profile, a phenomenon that might be explained by internalization (at $10 \mathrm{~min}$ PI) with subsequent reconstitution (starting at $40 \mathrm{~min} \mathrm{PI}$ ) of this receptor. The expression of TLR4, as well as its coreceptor, $C D 14$, showed a similar biphasic change as observed with C5aR. In addition, changes in the mRNA expression levels of several genes belonging to the TLR4

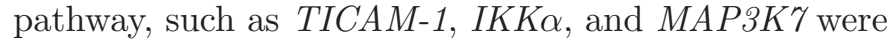
noted. The maximal expression of TLR4, CD14, and $C 5 a R$ mRNA at 80 min PI was accompanied by a peak in IL8 mRNA, indicating that $\mathrm{C} 5 \mathrm{a}$ is able to induce IL-8 production in neutrophils in vitro without the need of a costimulatory factor such as lipopolysaccharide. Moreover, a relatively constant expression of $R E L A$ was accompanied by increased expression of ATF3, an endogenous inhibitor of nuclear factor- $\kappa \mathrm{B}$ mediated transcription, implying that C5a regulates TLR4 signaling and IL-8 synthesis independently. A significant time-dependent correlation was found between $C 5 a R$ and TLR 4, with the majority of the selected TLR4dependent genes showing a significant correlation with C5aR at 80 min PI, when C5aR and TLR4 mRNA
\end{abstract}

Received April 21, 2010.

Accepted October 1, 2010.

${ }^{1}$ Corresponding author: christian.burvenich@ugent.be expression reached its maximum, suggesting crosstalk between both receptors. Taken together, this study showed that $\mathrm{C} 5 \mathrm{a}$ is able to (1) alter the expression of genes belonging to the TLR4 pathway and (2) induce IL8 gene expression in bovine neutrophils. In addition, indications for cross-talk between complement activation and TLR4 signaling were found in the present study.

Key words: complement component 5a, neutrophil, sepsis, toll-like receptor 4

\section{INTRODUCTION}

The activation of the complement system is a key feature in the humoral defense against invading microorganisms. Despite the beneficial effects of this system, inappropriate or excessive complement activation leads to harmful effects in the host. Sepsis is the result of a temporal and spatial mismatch in inflammatory reactions, and is associated with uncontrolled infection. One of the complement activation products with major potential for harm is anaphylatoxin complement component 5a (C5a; Guo and Ward, 2005). This 74- to 77-AA peptide is cleaved from C5 during complement activation and, depending on the species, undergoes post-translational modifications (Gennaro et al., 1986). Complement component $5 \mathrm{a}$ has a broad spectrum of biological functions, but all actions appear to be mediated through a specific $\mathrm{G}$ protein-coupled $\mathrm{C} 5$ a receptor (C5aR) (Riedemann et al., 2003).At low concentrations, C5a induces and possibly enhances neutrophil chemotaxis, adhesion and transmigration, oxidative burst, phagocytosis, and delays neutrophil apoptosis (Guo et al., 2004). During sepsis, when C5a is produced in high concentrations, neutrophils have reduced immune functions, which could lead to an inability to eliminate bacteria (Riedemann et al., 2003).

Following infection, an immune response is initiated by cell surface receptors, such as toll-like receptors (TLR). Toll-like receptors detect pathogens and trigger signaling pathways, which lead to the production 
of cytokines and chemokines. Gram-negative bacteria such as Escherichia coli contain LPS, which is recognized by TLR4 (Beutler et al., 2001). Although TLR4 is able to recognize LPS by itself, binding is facilitated by accessory molecules such as cluster of differentiation 14 (CD14; Lloyd and Kubes, 2006), LPS binding protein (Jack et al., 1997), and MD2 (Fitzgerald et al., 2004). Ligand binding of LPS to the TLR4/MD2/CD14 complex induces dimerization of the TLR4 receptor, necessary for the recruitment of downstream signaling molecules, which can occur via a myeloid differentiation primary response gene 88 (MyD88)-dependent or -independent pathway (TRIF-dependent pathway; Akira and Hoshino, 2003). More recently, it has been demonstrated that aside from MyD88, another molecule, namely spleen tyrosine kinase (Syk; Sada et al., 2001), is constitutively associated with TLR4, although the exact interaction is unknown to date (Chaudhary et al., 2007). The MyD88 cascade signaling starts with the activation of MyD88 and the recruitment of TRAF6. The TRAF6 is an adaptor protein that activates the MAP3K7 (also known as Tak1) complex (Xia et al., 2009). This complex then activates the IKK $\alpha$ complex, which allows the translocation of NF- $\kappa \mathrm{B}$ to the nucleus. The NF- $\kappa \mathrm{B}$ family is composed of homo- and heterodimers of Rel proteins; NF- $\kappa \mathrm{B} 1$ (p50), NF- $\kappa \mathrm{B} 2$ (p52), RELA (p65), RELB, and c-Rel (Rel). The p50/ RELA heterodimer is the most abundant form of NF$\kappa \mathrm{B}$ and the RELA subunit provides the gene regulatory function of this complex (Zhong et al., 1998; Chen et al., 2005). The NF- $\kappa \mathrm{B}$ translocation to the nucleus will result in the activation of several signaling pathways leading to the production of a variety of inflammatory mediators (IL-1 $\beta$, IL-6, IL-8, tumor necrosis factor- $\alpha$, Cox-2) and the upregulation of adhesion molecules like E-selectin, VCAM-1, and ICAM-1 (Tak and Firestein, 2001). Therefore, stringent regulation of these pathways is needed to prevent exaggerated expression of signaling components and proinflammatory cytokines that could evoke devastating effects on the host. Thus, it is essential that negative regulators act at multiple levels within the TLR4-signaling cascade. Known negative modulators of the TLR4 pathway include TRIAD3A, an intracellular zinc RING finger protein, which prevents TLR4 dimerization; PI3K, which inhibits downstream signaling; and ATF-3, which prevents binding of NF- $\kappa$ B to DNA (Chuang and Ulevitch, 2004; Gilchrist et al., 2006).

In the present study, we investigated the effect of the complement activator C5a on the expression of key genes belonging to the TLR4 pathway. To this end, bovine neutrophils were used as a model as it is known that (1) neutrophil function is depressed during clinical septic mastitis in cows (Burvenich et al., 2003), (2) high concentrations of C5a are produced during sepsis (Ward, 2004), and (3) C5a negatively regulates TLR4induced synthesis of cytokines in macrophages, another important cell type of the innate immunity (Hawlisch et al., 2005).

\section{MATERIALS AND METHODS}

\section{Blood Sampling and Isolation of Neutrophils}

Fifteen Holstein-Friesian cows, housed at the experimental dairy station of Ghent University (Biocentrum Agri-Vet Melle, Belgium), were blood sampled from the tail vein (Sears et al., 1978). The animals were clinically healthy and the absence of mastitis was confirmed by determination of the milk SCC of foremilk samples $(<200,000 / \mathrm{mL})$. Approval from the local ethical committee was obtained (EC2008/108). Fifty-milliliter blood samples were aseptically collected in Vacutainer tubes (Becton Dickinson, Erembodegem, Belgium) containing $150 \mu \mathrm{L}$ of EDTA as anticoagulant, and blood was processed within $0.5 \mathrm{~h}$ of collection. Blood leukocytes were isolated using density-gradient centrifugation according to Siemens et al. (2007). Briefly, red blood cells were lysed by adding $50 \mathrm{~mL}$ of RNase free water. Five milliliters of $10 \% \mathrm{NaCl}$ was added, and the sample was centrifuged at $585 \times g$ for $10 \mathrm{~min}$ at room temperature (RT). The supernatant was discarded and the pellet was resuspended in Hanks' balanced salt solution (HBSS; Invitrogen, Merelbeke, Belgium). Ten milliliters of the leukocyte suspension was layered on top of Histopaque 1077/1119 gradient (Sigma-Aldrich, Bornem, Belgium) and centrifuged at $440 \times g$ for $25 \mathrm{~min}$ at RT. After removal of the supernatant, neutrophils were washed by adding $50 \mathrm{~mL}$ of HBSS and centrifuged at $585 \times g$ for $10 \mathrm{~min}$ at RT.

\section{In Vitro Stimulation of Neutrophils}

The effect of C5a on expression of key genes from the TLR4 signaling pathway was analyzed by incubating neutrophils $\left(5 \times 10^{6}\right)$ with purified C5a $(50 \mathrm{ng} / \mathrm{mL})$ in preheated $\left(37^{\circ} \mathrm{C}\right)$ HBSS, supplemented with $\mathrm{Ca}^{2+}$, $\mathrm{Mg}^{2+}$, and $0.1 \%$ BSA (Roche, Vilvoorde, Belgium) for $0,10,20,40,80$, and $100 \mathrm{~min}$. The reaction was stopped by adding ice-cold PBS (Invitrogen), followed by centrifugation at $15,800 \times g$ for $3 \mathrm{~min}$. The cell pellets were washed twice with ice-cold PBS and kept on ice until RNA isolation.

\section{RNA Isolation}

One milliliter of total RNA isolation reagent (ABgene, Epsom, Surrey, UK) was added to the cells and samples were vortexed and placed on ice for $5 \mathrm{~min}$. 
Table 1. Primers used for reverse transcription quantitative real-time PCR of the reference genes

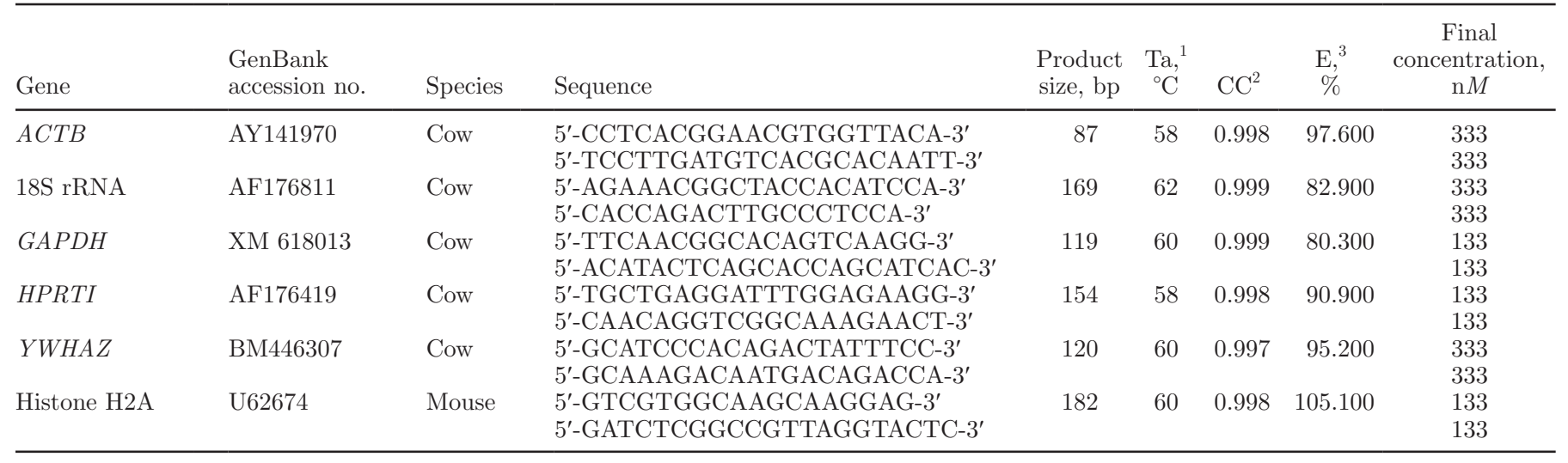

${ }^{1}$ Annealing temperature.

${ }^{2}$ Correlation coefficient.

${ }^{3} \mathrm{PCR}$ efficiency.

Next, $200 \mu \mathrm{L}$ of chloroform (Sigma-Aldrich) was added and the samples were vortexed for another $15 \mathrm{~s}$. After $5 \mathrm{~min}$ on ice, the samples were centrifuged for $15 \mathrm{~min}$ at $12,000 \times g$, which resulted in 3 visible phases. The upper aqueous phase, which contained the RNA, was transferred to a new microcentrifuge tube and $500 \mu \mathrm{L}$ of isopropanol (Fiers, Kuurne, Belgium) was added. The samples were placed on ice $(10 \mathrm{~min})$ and centrifuged at $12,000 \times g$ for $10 \mathrm{~min}$. The supernatant was discarded and the pellet was rinsed twice with $1 \mathrm{~mL}$ of RNase-free ethanol (75\%; Fiers). The pellet was resuspended in 15 $\mu \mathrm{L}$ of preheated $\left(65^{\circ} \mathrm{C}\right)$ RNase-free $10 \mathrm{~m} M$ Tris- $\mathrm{HCl}$ (pH 8.0; VWR International, Leuven, Belgium).

DNase Treatment. Four microliters of RQ1 RNasefree DNase (Promega, Leiden, the Netherlands) and $2 \mu \mathrm{L}$ of RQ1 DNase reaction buffer (Promega) were added to $14 \mu \mathrm{L}$ of RNA at $37^{\circ} \mathrm{C}$ for $30 \mathrm{~min}$. Finally, 2 $\mu \mathrm{L}$ of RQ1 DNase stop solution (Promega) was added and the mixture was incubated for $10 \mathrm{~min}$ at $65^{\circ} \mathrm{C}$.

To exchange the buffer, the RNA was subsequently transferred to a YM-100 microcon tube (Millipore, Brussels, Belgium), $100 \mu \mathrm{L}$ of RNase-free $10 \mathrm{~m} M$ Tris$\mathrm{HCl}(\mathrm{pH} 8)$ was added, and the column was centrifuged for $12 \mathrm{~min}$ at $500 \times g\left(4^{\circ} \mathrm{C}\right)$. This step was repeated once. Next, $15 \mu \mathrm{L}$ of RNase-free $10 \mathrm{~m} M$ Tris- $\mathrm{HCl}(\mathrm{pH}$ 8) was added, and the column was inverted in a new microcentrifuge tube and centrifuged for $3 \mathrm{~min}$ at 1,000 $\times g\left(4^{\circ} \mathrm{C}\right)$.

Minus RT Control. To ensure that DNase treatment was successful, a minus RT control PCR was performed on the iCycler iQ real-time PCR detection system (Bio-Rad, Nazareth-Eke, Belgium) in a total volume of $15 \mu \mathrm{L}$ containing $2 \times$ KAPA SYBR FAST qPCR Master Mix Bio-Rad iCycler (KAPA Biosystems, Woburn, MA), GAPDH primers (Table 1), and $2.5 \mu \mathrm{L}$ of template (RNA, genomic DNA as positive control and water as negative control). The quantitative (q)PCR reaction consisted of a 3-min enzyme activation step at $95^{\circ} \mathrm{C}$, followed by 40 amplification cycles (denaturation for $3 \mathrm{~s}$ at $95^{\circ} \mathrm{C}$ and annealing/elongation/SYBR detection for $30 \mathrm{~s}$ at $60^{\circ} \mathrm{C}$ ) and a melt curve analysis (from 75 to $90^{\circ} \mathrm{C}$ with $0.3^{\circ} \mathrm{C}$ increments of $10 \mathrm{~s}$ ). The amplification products were additionally analyzed on a $2 \%$ agarose gel. The quantity and quality of the DNA-free RNA was measured by spectrophotometric absorbance at $260 \mathrm{~nm}$ (Nanodrop ND-1000 spectrophotometer, Isogen Life Science, Sint-Pieters-Leeuw, Belgium) and $0.8 \%$ agarose gel electrophoresis.

\section{cDNA Synthesis}

The ImProm-II reverse transcription system (Promega) was used for cDNA synthesis. Briefly, $0.8 \mu \mathrm{L}$ of $0.5 \mu \mathrm{g} / \mu \mathrm{L}$ oligodT and $0.8 \mu \mathrm{L}$ of $0.5 \mu \mathrm{g} / \mu \mathrm{L}$ random hexamers were added to $10 \mu \mathrm{L}$ of RNA (up to $1 \mu \mathrm{g}$ ). The mixture was incubated at $70^{\circ} \mathrm{C}$ for 5 min and immediately put on ice for $5 \mathrm{~min}$. Next, $4 \mu \mathrm{L}$ of $5 \times \mathrm{Im}$ Prom-II reaction buffer, $2.4 \mu \mathrm{L}$ of $25 \mathrm{mM} \mathrm{MgCl}, 1 \mu \mathrm{L}$ of dNTP (10 mM each dNTP), and $1 \mu \mathrm{L}$ of ImProm-II reverse transcriptase $(200 \mathrm{U})$ were added. The mixture was incubated for $5 \mathrm{~min}$ at $25^{\circ} \mathrm{C}, 60 \mathrm{~min}$ at $42^{\circ} \mathrm{C}$, and $15 \mathrm{~min}$ at $70^{\circ} \mathrm{C}$. The cDNA was diluted 10 times in 10 $\mathrm{m} M$ Tris- $\mathrm{HCl}$ ( $\mathrm{pH} 8$ ), and a cDNA control PCR was performed in exactly the same way as the minus RT control PCR.

\section{Primer Design}

The primers used for the reference genes were designed and optimized by Goossens et al. (2005) and are shown 
in Table 1. Primers for the target genes were designed using the Primer3 software (http://www.sk.embnet. org/cgi-bin/primer3; based on an unpublished preliminary study performed earlier at our laboratory and the available sequences of the genes: http://www.ncbi.nlm. nih.gov). The optimal annealing temperature was set at $60^{\circ} \mathrm{C}$; the optimal GC-content at $50 \%$, and the maximal self complementarity was kept as low as possible. The presence of secondary structures in the amplicon was checked using "mfold" (http://www.bioinfo/rPI.edu/ applications/mfold/dna), whereas the specificity was checked with the Basic Local Alignment Search Tool at NCBI (http://www.ncbi.nlm.nih.gov/BLAST). Primers were produced by Sigma-Aldrich.

\section{Optimizing the Reverse Transcription Quantitative Real-Time PCR Assays}

All optimizations were performed on the iCycler iQ RT-qPCR detection system from Bio-Rad as described for the minus RT control PCR. The optimal annealing temperature was determined by gradient RT-qPCR (5 different temperatures between $55^{\circ} \mathrm{C}$ and $65^{\circ} \mathrm{C}$ ). The PCR efficiency and the correlation coefficient were determined by performing reverse transcription (RT)qPCR on a $1 / 4$ serial dilution series of 5 points at the optimal annealing temperature. The specificity of the PCR products was characterized by melt curve analysis and by sizing after conventional agarose gel electrophoresis (before and after performing a specific restriction digest). Their optimal conditions are shown in Table 2 .

\section{$R T-q P C R$ Experiments}

Per target gene, the cycle threshold values of the samples were transformed to raw quantities according to the comparative cycle threshold method (Vandesompele et al., 2002). Normalization of the RT-qPCR data was done as described by De Ketelaere et al. (2006). Briefly, 6 reference genes belonging to different functional classes were selected (Table 1). Reference gene expression stability was determined using the geNorm Visual Basic application for Microsoft Excel (Vandesompele et al., 2002). Four genes with the highest gene expression stability values, the 4 most stable reference genes were selected for normalization of the target gene expression levels (Figure 1). The normalization factor was calculated using the geometric mean of the raw quantities of the 4 reference genes. The raw quantities of the target genes were divided by the normalization factor to become the relative expression level. A logtransformation was done to allow for statistical analysis of the RT-qPCR data.

\section{Statistics}

Data are expressed as means \pm SEM. The statistical evaluation of the data was performed by a mixed model with time, lactation stage, and their interaction as fixed effects, and cow as random effect. The different time points were compared pairwise with zero using Dunnett's multiple comparisons technique at a global significance level of 5\%. Pearson correlation coefficients between gene expression levels were calculated at 5 and $1 \%$ significance levels for each time point.

\section{RESULTS}

\section{C5a Incubation Results in a Biphasic Change in C5a Receptor Expression}

First, we wanted to investigate the effect of C5a on its own receptor, C5aR, as a downregulation of C5aR in neutrophils (as observed during sepsis) has been correlated with the inhibition of proper innate immune functions of these cells (Riedemann et al., 2003). Therefore, blood samples were taken from cows in mid lactation, at d 170 postpartum, because these neutrophils can be considered immune-competent (Stevens et al., 2011). At time $0,50 \mathrm{ng} / \mathrm{mL}$ of C5a was added to these blood neutrophils and at different time points (0 up to $100 \mathrm{~min}$ ) postincubation (PI), the expression of C5aR was analyzed and statistically compared with the expression before C5a stimulation. The expression of the C5a receptor in neutrophils from mid lactating cows was downregulated within $10 \mathrm{~min}$ PI compared with time 0 (Figure 2A). The transcripts for the $C 5 a R$ gene further decreased significantly up to 40 PI, after which the expression level of $C 5 a R$ increased again and became comparable to the expression level before C5a stimulation at 100 PI (the end of the experiment; Figure 2A).

To study the effect of the lactation stage on $C 5 a R$ expression in neutrophils, this experiment was repeated with neutrophils from cows in different lactation stages (12-334 d of lactation; Figure 2B). In cows at $82 \mathrm{~d}$ of lactation, a downregulation of $C 5 a R$ transcripts was observed (which reached significance at $10 \mathrm{~min}$ PI), followed by an increase in expression to prestimulation levels (Figure 2B). When transcript levels of $C 5 a R$ were analyzed in cows at 12,256 , and $334 \mathrm{~d}$ of lactation, no time-dependent changes could be observed in C5aR expression, nor was a significant relationship found between C5aR transcript levels and lactation stage. Because of the lack of a significant effect of lactation stage on C5aR expression, data from cows between 12 and $334 \mathrm{~d}$ of lactation were pooled and represented as mean per time point in all further experiments. 
Table 2. Primers used for reverse transcription quantitative real-time PCR of target genes

\begin{tabular}{|c|c|c|c|c|c|c|c|c|}
\hline Gene & $\begin{array}{l}\text { GenBank } \\
\text { accession no. }\end{array}$ & Species & Sequence & $\begin{array}{l}\text { Product } \\
\text { size, bp }\end{array}$ & $\underset{{ }^{\circ} \mathrm{C},{ }^{1}}{\mathrm{~T}}$ & $\mathrm{CC}^{2}$ & $\begin{array}{l}\mathrm{E}^{3} \\
\%\end{array}$ & $\begin{array}{c}\text { Final } \\
\text { concentration, } \\
\mathrm{n} M\end{array}$ \\
\hline TLR4 & NM_174198 & Cow & $\begin{array}{l}\text { 5'-CAGGGCAGGGAAAGTCAA-3' } \\
\text { 5'-AGGAAAAGTGAGCCAAGACC-3' }\end{array}$ & 203 & 59 & 0.997 & 92.9 & $\begin{array}{l}333 \\
333\end{array}$ \\
\hline$C D 14$ & NM_174008 & Cow & $\begin{array}{l}\text { 5'-GAAGAGAGGGAAGAGGAATGAATT-3' } \\
\text { 5'-TAATAAGGATGGGGCAGAAGG-3' }\end{array}$ & 100 & 58 & 0.999 & 107.6 & $\begin{array}{l}133 \\
133\end{array}$ \\
\hline MD2 & XM_864835 & Cow & $\begin{array}{l}\text { 5'-AGCAGATTGGGTTCCTTTTG-3' } \\
\text { 5'-AAATGATGTCACTCGGGTAGG-3' }^{\prime}\end{array}$ & 154 & 59 & 0.995 & 86.5 & $\begin{array}{l}333 \\
333\end{array}$ \\
\hline$M Y D 88$ & NM_001014382 & Cow & $\begin{array}{l}\text { 5'-CGCACAGACATACAGGCATC-3' } \\
\text { 5'-GGTCCCAGTGAAAAAGGAAAA-3' }\end{array}$ & 153 & 63 & 0.998 & 91.8 & $\begin{array}{l}333 \\
333\end{array}$ \\
\hline Syk & NM_001037465 & Cow & $\begin{array}{l}\text { 5'-ACAAGGACAAAACGGGGAAG-3' } \\
\text { 5'-TGGCTCGTAAGGGTTGAATG-3' }\end{array}$ & 248 & 61 & 0.997 & 103.8 & $\begin{array}{l}333 \\
333\end{array}$ \\
\hline TICAM-1 & NM_001030301 & Cow & $\begin{array}{l}\text { 5'-GGAGTCGTCCGAGCAGAAA-3' } \\
\text { 5'-AGGATGATGAATGCCGAGTG-3' }^{\prime}\end{array}$ & 201 & 61 & 1.000 & 84.0 & $\begin{array}{l}333 \\
333\end{array}$ \\
\hline TRAF6 & NM_001034661 & Cow & $\begin{array}{l}\text { 5'-TGAAATCGCAAGAAGAGGAGA-3' } \\
\text { 5'-TGCATCGTGTGGACAAAGAG-3' }\end{array}$ & 154 & 60 & 0.997 & 95.9 & $\begin{array}{l}333 \\
333\end{array}$ \\
\hline МAРЗК' & NM_001081595 & Cow & $\begin{array}{l}\text { 5'-CGCTTCTTCTTCTTCCTCGT-3' } \\
\text { 5'-GCTCCTCTTCCAACAACCTC-3' }\end{array}$ & 120 & 59 & 0.998 & 95.5 & $\begin{array}{l}333 \\
333\end{array}$ \\
\hline$I K K \alpha$ & XM_863907 & Cow & 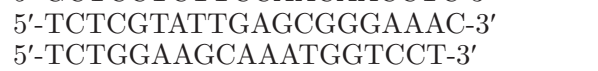 & 189 & 60 & 0.998 & 96.9 & $\begin{array}{l}333 \\
333\end{array}$ \\
\hline$R E L A$ & NM_001080242 & Cow & $\begin{array}{l}\text { 5'- GCATCCAGACCAACAACAAC-3' } \\
5^{\prime}-\text { CTCCCAGAGTTCCGATTCAC-3' }\end{array}$ & 217 & 60 & 0.999 & 94.8 & $\begin{array}{l}333 \\
333\end{array}$ \\
\hline$I L-8$ & NM_173925 & Cow & $\begin{array}{l}\text { 5'-CTGCCTAAACCCCAAGGAA-3' } \\
\text { 5'-AACCCTACACCAGACCCACA-3' }\end{array}$ & 206 & 60 & 0.999 & 82.4 & $\begin{array}{l}333 \\
333\end{array}$ \\
\hline TRIAD3A & XM_883230 & Cow & $\begin{array}{l}\text { 5'-GTGTTCCCGATGCTCTCTCT-3' } \\
\text { 5'-CGATGCGTTTGAAGGTGTT-3' }\end{array}$ & 125 & 62 & 0.999 & 90.2 & $\begin{array}{l}333 \\
333\end{array}$ \\
\hline PI3K & NM_174574 & Cow & $\begin{array}{l}\text { 5'-GTTACCCAAGAAGCAGAAAGG-3' } \\
5^{\prime} \text {-ATGCCGATAGCAAAACCAA-3' }\end{array}$ & 152 & 59 & 1.000 & 107.6 & $\begin{array}{l}333 \\
333\end{array}$ \\
\hline ATF3 & NM_001046193 & Cow & $\begin{array}{l}\text { 5'-ACTGGTGTTTGAGGATTTTGCT-3' } \\
\text { 5'-GCAGGCACTCTGTCTTCTCC-3' }\end{array}$ & 260 & 64 & 1.000 & 90.2 & $\begin{array}{l}333 \\
333\end{array}$ \\
\hline$C 5 a R$ & NM_001007810 & Cow & $\begin{array}{l}\text { 5'- ACTGGTCCTTTGGTGATGCT-3' } \\
5^{\prime}-\text { GTGGGAAGTGGTCTATGTGG-3' }\end{array}$ & 249 & 60 & 0.999 & 101.5 & $\begin{array}{l}333 \\
333\end{array}$ \\
\hline
\end{tabular}

${ }^{1}$ Annealing temperature.

${ }^{2}$ Correlation coefficient.

${ }^{3} \mathrm{PCR}$ efficiency. 


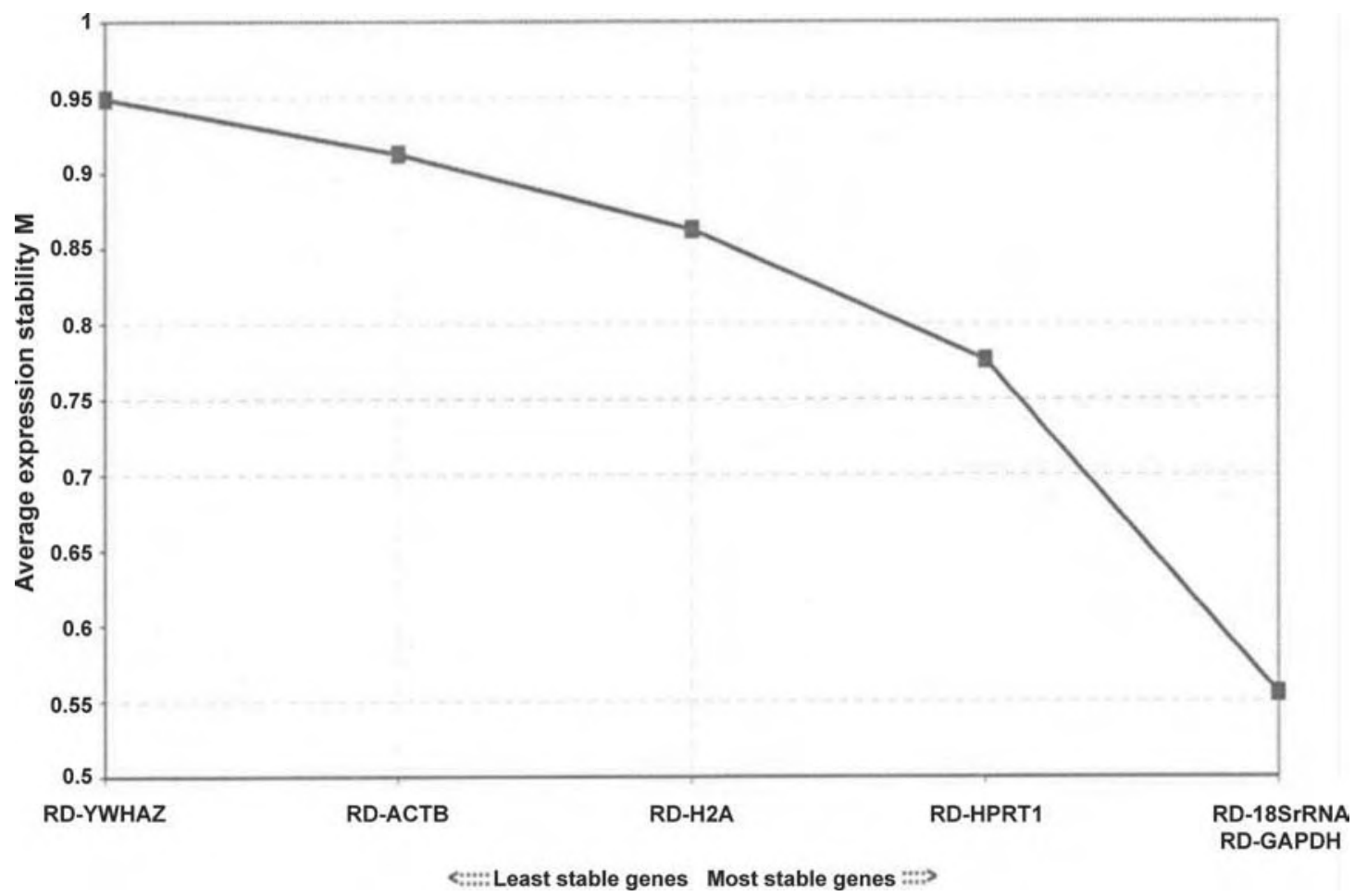

Figure 1. Reference gene expression stability (M) was determined using the geNorm Visual Basic application. Four genes (RD-H2A, RDHPRT1, RD-18S rRNA, and RD-GAPDH) with the highest M-value were selected for normalization of the expressions of the target genes.

\section{C5a Induces Changes in the Expression Levels of Genes of the TLR4 Pathway}

A significant upregulation of mRNA levels of TLR4 and its coreceptor CD14 were observed following C5a stimulation (Figure 3 ). In general, gene transcripts were significantly upregulated at $40 \mathrm{~min}$ PI and peaked at 80 min PI. At 100 min PI, expression of TLR 4 reached preincubation levels, whereas expression levels of $C D 14$ remained significantly elevated $(P<0.05$; Figure 3$)$.

The genes involved in the subsequent steps of the TLR4 signaling pathway were also affected by C5a but in different ways. For $S y k, M A P 3 K \boldsymbol{Y}$, and $I K K \alpha$, a significant $(P<0.05)$ decrease of the expression level was noted at $10 \mathrm{~min}$ PI, which was restored to preincubation levels between 20 and 40 min PI. Starting from $80 \mathrm{~min}$ PI, the expression of Syk, MAP3K 7 , and $I K K \alpha$ decreased again compared with the starting level at time $0(P<0.05)$. Expression levels of TRAF6 and $M y D 88$ did not significantly change within the first 80 min PI, but starting from 80 min PI, their expression decreased and reached significance at $100 \mathrm{~min}$ PI $(P<$ 0.05 , Figure 3). In contrast to all previously discussed genes, mRNA expression of TICAM-1 did not show a decrease within 10 min PI, but increased to peak at 40 $\min \mathrm{PI}(P<0.05)$ and remained elevated up to $80 \mathrm{~min}$ PI $(P<0.05$, Figure 3$)$. Finally, the expression levels of the nuclear factor- $\kappa \mathrm{B}$ subunit RELA and the TLR4 adaptor protein gene $M D 2$ were not altered during the entire incubation period (Figure 3 ).

\section{C5a Induces Changes in Expression Levels of Inhibiting Genes of the TLR4 Pathway}

The C5a had different effects on the expression of genes, with an inhibitory function in the TLR4 signaling pathway. The expression of the inhibitor TRIAD $3 A$ decreased after C5a incubation, which reached significance at 80 and $100 \mathrm{~min}$ PI (Figure $4, P<0.05$ ). The mRNA expression of PI3K, a downstream protein, showed significant downregulation that started within the first $10 \mathrm{~min}$ PI and slowly decreased until $100 \mathrm{~min}$ PI (Figure $4, P<0.05$ ). In contrast to TRIAD $3 A$ and PI3K, ATF3, an inhibitor of NF- $\mathrm{KB}$, showed a strong upregulation of mRNA levels within the first $10 \mathrm{~min}$ of C5a incubation (Figure 4, $P<0.05$ ). This expression further increased until 40 min PI, and remained elevated up to 100 min PI (end of the experiment; Figure 4).

\section{C5a Has an Effect on IL-8 Expression}

It was demonstrated by Pearl-Yafe et al. (2007) that TLR 4 expression in neutrophils is enhanced by LPS and IFN- $\gamma$, which leads to an enhanced secretion of 


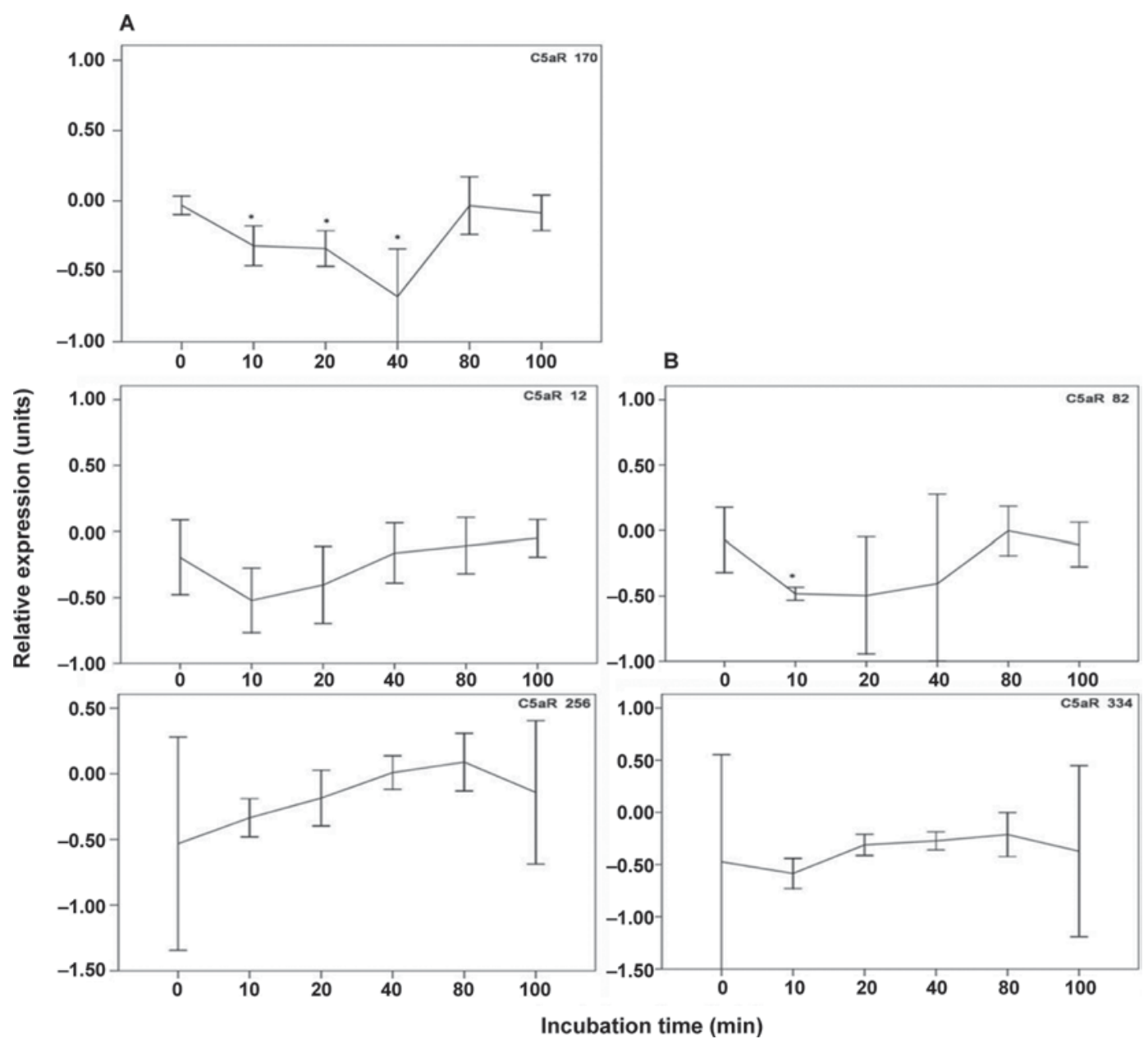

Figure 2. The effect of complement component $5 \mathrm{a}(\mathrm{C} 5 \mathrm{a})$ on $\mathrm{C} 5 \mathrm{a}$ receptor $(\mathrm{C} 5 \mathrm{aR})$ expression in cows from different lactation stages. Bovine blood neutrophils $\left(5 \times 10^{6}\right)$ were incubated with $50 \mathrm{ng} / \mathrm{mL}$ of purified C5a for $0,10,20,40,80$, or $100 \mathrm{~min}$ at $37^{\circ} \mathrm{C}$ and $5 \% \mathrm{CO}_{2}$. Time zero $(0$ min) was used as a control to compare changes in the relative expression. *Significant changes are indicated by an asterisk $(P<0.05)$. For each time point, the mean expression was calculated and data are presented as mean \pm SEM. The (A) $C 5 a R$ gene expression of bovine neutrophils from 3 cows at $170 \mathrm{~d}$ of lactation and (B) C5aR gene expression of bovine neutrophils from cows at 12, 82, 256, and 334 d of lactation.

cytokines such as IL-8. Therefore, we investigated the effect of C5a incubation on $I L 8$ gene expression, as this is a key gene in the TLR4 signaling pathway. The $I L 8$ mRNA transcripts at time 0 were very low, but upon addition of C5a, a significant upregulation within the first 10 min PI was observed. Expression peaked at 40 min PI and remained significantly elevated until 100 min PI (Figure 5; $P<0.05$ ).

\section{Correlation Coefficient Between the TLR4 Pathway and C5aR}

Correlations were calculated between the relative expression of genes belonging to the TLR4 pathway on the one hand and C5aR on the other hand. At baseline levels ( 0 min PI), the highest correlation was found be- tween $C 5 a R$ and ATF3, an inhibitor gene of the TLR4 signaling pathway (Table 3 ). In addition, other significant positive correlations were found between $\mathrm{C} 5 \mathrm{aR}$ and MD2, MyD88, IKK $2, R E L A$, and TRIAD3A; and negative correlations were found between $C 5 a R$ and TICAM-1, MAP3K 7 , and IL8 (Table 3). After the addition of C5a, however, these correlations changed. The salient findings were that at $40 \mathrm{~min}$ PI, the expression of most genes belonging to the TLR4 pathway were significantly correlated with $C 5 a R$ and a high correlation was found between $C 5 a R$ and TLR 4, MyD88, and PI3K (with a correlation of almost $90 \%$ at 100 min PI) and between C5aR and CD14, MD2, and TRAF6 (with a correlation of almost $82 \%$ at 100 min PI; Table 3). On the other hand, the positive correlation between $C 5 a R$ and $I K K \alpha$ completely disappeared after stimula- 

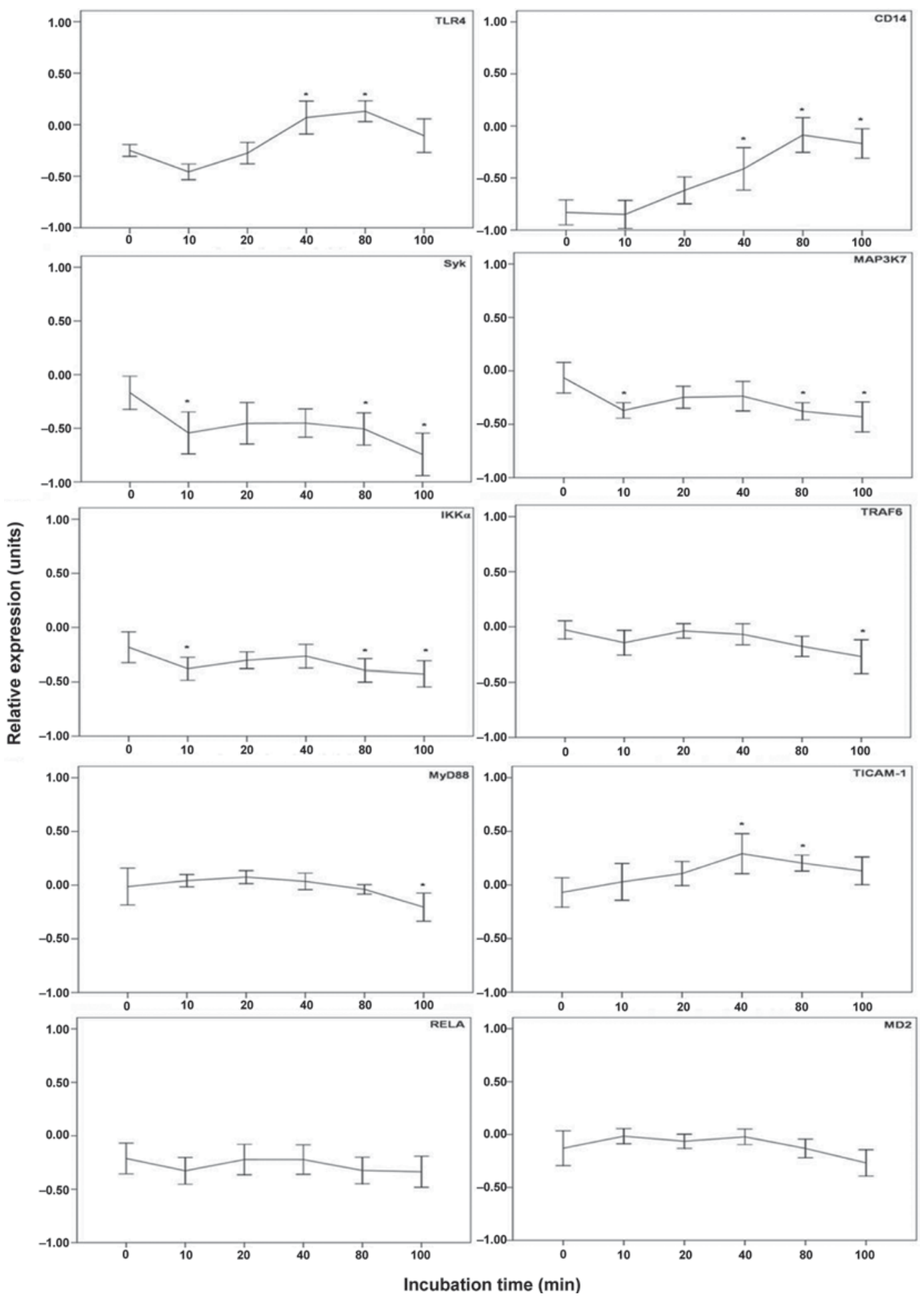

Figure 3. The effect of complement component 5a (C5a) stimulation on toll-like receptor 4 (TLR4) signaling in bovine neutrophils. Blood neutrophils $\left(5 \times 10^{6}\right)$ were incubated with $50 \mathrm{ng} / \mathrm{mL}$ of purified C5a for $0,10,20,40,80$, or $100 \mathrm{~min}$ at $37^{\circ} \mathrm{C}$ and $5 \% \mathrm{CO}_{2}$. Time zero $(0 \mathrm{~min})$ was used as a control to compare changes in the expression. *Significant changes are indicated by an asterisk $(P<0.05)$. For each time point, the mean from 3 cows was calculated and data are presented as mean \pm SEM. 


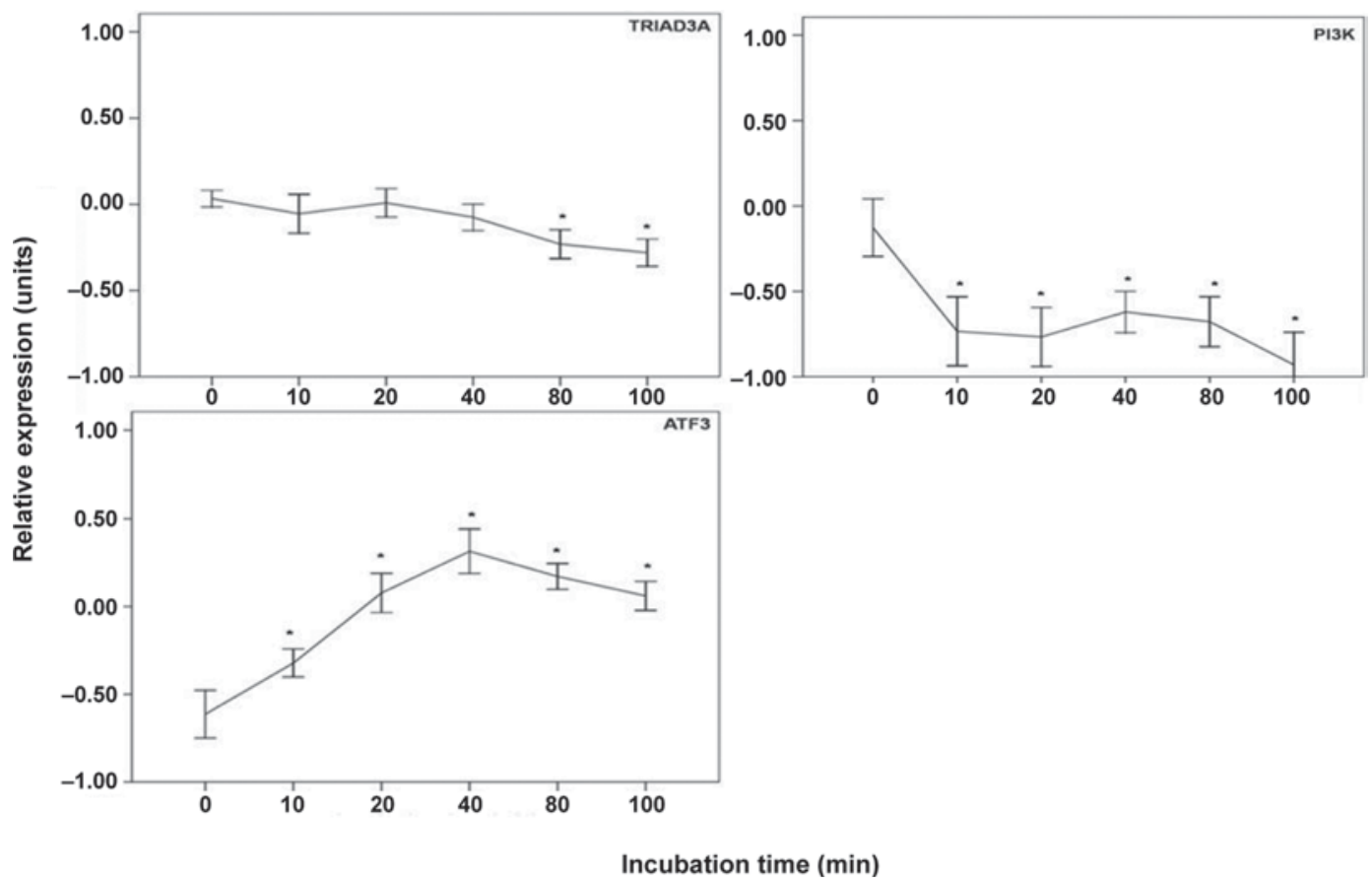

Figure 4. The effect of complement component 5a (C5a) on endogenous inhibitory genes of the toll-like receptor 4 (TLR4) signaling pathway. Bovine blood neutrophils $\left(5 \times 10^{6}\right)$ were incubated with $50 \mathrm{ng} / \mathrm{mL}$ of purified C5a for $0,10,20,40,80$, or $100 \mathrm{~min}$ at $37^{\circ} \mathrm{C}$ and $5 \% \mathrm{CO}_{2}$. Time zero $(0 \mathrm{~min})$ was used as a control to compare changes in the expression. ${ }^{*}$ Significant changes are indicated by an asterisk $(P<0.05)$. For each time point, the mean from 3 cows was calculated and data are presented as mean \pm SEM.

tion with C5a. For all other genes tested, correlations varied depending on the time point of $\mathrm{C} 5$ a incubation (Table 3).

\section{DISCUSSION}

Toll-like receptor signaling and complement activation are critical pathways regulating innate immunity. Previous studies demonstrated that the bovine mammary gland depends mainly on these mechanisms to defend itself against invading pathogens (see reviews by Burvenich et al., 2003; Rainard, 2003).

There is growing interest in the effect of the complement factor C5a on bovine neutrophils and, recently, the C5a/C5aR system has been molecularly characterized in these cells (Nemali et al., 2008). It appears that $\mathrm{C} 5 \mathrm{aR}$ is highly expressed in resting bovine neutrophils, which were fully responsive to C5a without the need to prime for upregulation of the receptor (Nemali et al., 2008). In our study, a concentration of $50 \mathrm{ng} / \mathrm{mL}$ was used to stimulate the neutrophils as previous work has demonstrated that (1) a C5a concentration ranging from 1 to $50 \mathrm{ng} / \mathrm{mL}$ is sufficient to stimulate neutrophils in vitro (Gennaro et al., 1986) and (2) a peak concentration of $50 \mathrm{ng} / \mathrm{mL}$ of C5a can be found in secreta from infected mammary glands during experimentally induced E. coli mastitis in vivo (Shuster et al., 1997).
The role of the C5a-C5aR system in sepsis has been studied in an in vivo rat model of cecal ligation and puncture (Guo et al., 2003). They demonstrated that

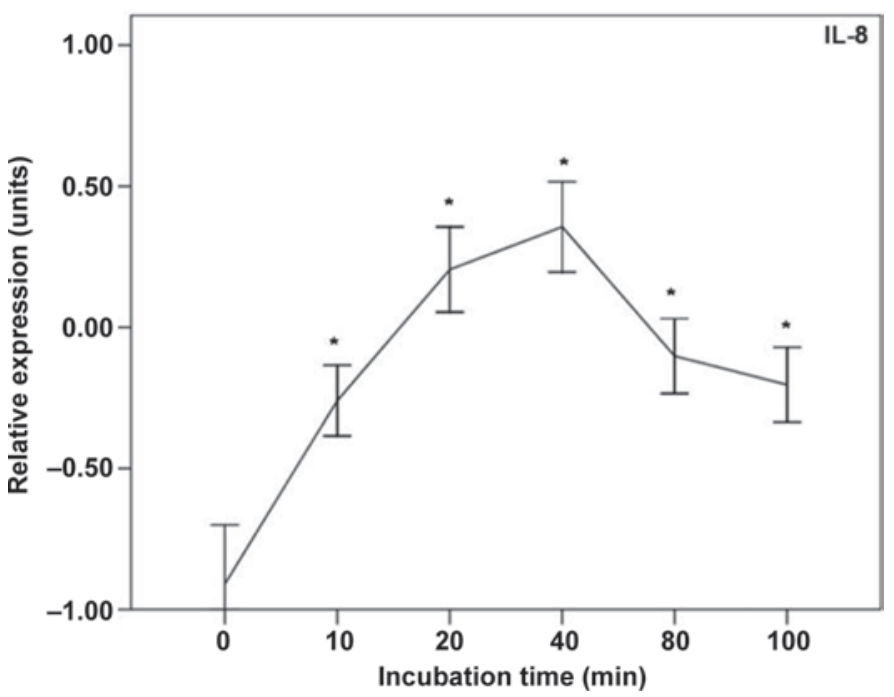

Figure 5. The effect of complement component 5a (C5a) stimulation on IL-8 expression in bovine neutrophils. Blood neutrophils $(5 \times$ $10^{6}$ ) were incubated with $50 \mathrm{ng} / \mathrm{mL}$ of purified C5a for $0,10,20,40$, 80 , or $100 \mathrm{~min}$ at $37^{\circ} \mathrm{C}$ and $5 \% \mathrm{CO}_{2}$. Time zero $(0 \mathrm{~min})$ was used as a control to compare changes in the expression. ${ }^{*}$ Significant changes are indicated by an asterisk $(P<0.05)$. For each time point, the mean from 3 cows was calculated and data are presented as mean \pm SEM. 
Table 3. Correlation coefficients between transcript abundance for complement component 5a receptor (C5aR) and genes related to the toll-like receptor 4 (TLR4) pathway at 0 , $10,20,40,80$, and 100 min postincubation

\begin{tabular}{|c|c|c|c|c|c|c|c|c|c|c|c|c|}
\hline \multirow[b]{2}{*}{ Gene } & \multicolumn{2}{|c|}{0} & \multicolumn{2}{|c|}{10} & \multicolumn{2}{|c|}{20} & \multicolumn{2}{|c|}{40} & \multicolumn{2}{|c|}{80} & \multicolumn{2}{|c|}{100} \\
\hline & Mean & $\mathrm{cc}^{2}$ & Mean & $\mathrm{cc}$ & Mean & $\mathrm{cc}$ & Mean & $\mathrm{cc}$ & Mean & $\mathrm{cc}$ & Mean & $\mathrm{cc}$ \\
\hline TLR4 & $\begin{array}{c}-0.283 \\
(0.061)\end{array}$ & 0.181 & $\begin{array}{c}-0.458 \\
(0.057)\end{array}$ & $0.762^{* *}$ & $\begin{array}{c}-0.276 \\
(0.057)\end{array}$ & $0.804^{* *}$ & $\begin{array}{c}0.069 \\
(0.057)\end{array}$ & $0.827^{* *}$ & $\begin{array}{c}0.130 \\
(0.057)\end{array}$ & 0.474 & $\begin{array}{c}-0.107 \\
(0.057)\end{array}$ & $0.888^{* *}$ \\
\hline$C D 14$ & $\begin{array}{c}-0.863 \\
(0.0753)\end{array}$ & 0.034 & $\begin{array}{c}-0.849 \\
(0.072)\end{array}$ & 0.299 & $\begin{array}{c}-0.618 \\
(0.072)\end{array}$ & 0.493 & $\begin{array}{c}-0.412 \\
(0.072)\end{array}$ & $0.785^{* *}$ & $\begin{array}{c}-0.087 \\
(0.072)\end{array}$ & $0.565^{*}$ & $\begin{array}{c}-0.169 \\
(0.072)\end{array}$ & $0.814^{* *}$ \\
\hline Syk & $\begin{array}{c}-0.216 \\
(0.088)\end{array}$ & 0.416 & $\begin{array}{c}-0.578 \\
(0.076)\end{array}$ & 0.507 & $\begin{array}{c}-0.454 \\
(0.073)\end{array}$ & $0.641^{*}$ & $\begin{array}{c}-0.423 \\
(0.076)\end{array}$ & 0.419 & $\begin{array}{c}-0.506 \\
(0.073)\end{array}$ & $0.529 *$ & $\begin{array}{c}-0.744 \\
(0.076)\end{array}$ & $0.719^{* *}$ \\
\hline MD2 & $\begin{array}{c}-0.132 \\
(0.051)\end{array}$ & $0.629^{*}$ & $\begin{array}{c}-0.016 \\
(0.049)\end{array}$ & 0.132 & $\begin{array}{c}-0.064 \\
(0.049)\end{array}$ & -0.295 & $\begin{array}{c}-0.035 \\
(0.051)\end{array}$ & $0.606^{*}$ & $\begin{array}{c}-0.132 \\
(0.049)\end{array}$ & -0.329 & $\begin{array}{c}-0.266 \\
(0.051)\end{array}$ & $0.810^{* *}$ \\
\hline TICAM-1 & $\begin{array}{c}-0.103 \\
(0.070)\end{array}$ & $-0.598^{*}$ & $\begin{array}{c}0.057 \\
(0.072)\end{array}$ & -0.132 & $\begin{array}{c}0.105 \\
(0.068)\end{array}$ & $-0.720^{*}$ & $\begin{array}{c}0.263 \\
(0.075)\end{array}$ & $-0.678^{*}$ & $\begin{array}{c}0.193 \\
(0.063)\end{array}$ & -0.479 & $\begin{array}{c}0.110 \\
(0.065)\end{array}$ & $-0.615^{*}$ \\
\hline$M y D 88$ & $\begin{array}{c}-0.022 \\
(0.050)\end{array}$ & $0.774^{* *}$ & $\begin{array}{c}0.0412 \\
(0.048)\end{array}$ & $0.621^{*}$ & $\begin{array}{c}0.075 \\
(0.048)\end{array}$ & 0.478 & $\begin{array}{c}0.034 \\
(0.048)\end{array}$ & $0.784^{* *}$ & $\begin{array}{c}-0.040 \\
(0.048)\end{array}$ & 0.431 & $\begin{array}{r}-0.206 \\
(0.048)\end{array}$ & $0.866^{* *}$ \\
\hline TRAF6 & $\begin{array}{r}-0.036 \\
(0.048)\end{array}$ & 0.106 & $\begin{array}{c}-0.174 \\
(0.046)\end{array}$ & $0.686^{* *}$ & $\begin{array}{c}-0.035 \\
(0.046)\end{array}$ & $0.638^{*}$ & $\begin{array}{c}-0.065 \\
(0.048)\end{array}$ & $0.655^{*}$ & $\begin{array}{c}-0.178 \\
(0.045)\end{array}$ & $0.611^{*}$ & $\begin{array}{c}-0.276 \\
(0.046)\end{array}$ & $0.814^{* *}$ \\
\hline МАРЗК' & $\begin{array}{c}-0.055 \\
(0.053)\end{array}$ & -0.470 & $\begin{array}{c}-0.400 \\
(0.063)\end{array}$ & 0.534 & $\begin{array}{c}-0.269 \\
(0.060)\end{array}$ & 0.500 & $\begin{array}{r}-0.196 \\
(0.063)\end{array}$ & $-0.607^{*}$ & $\begin{array}{c}-0.374 \\
(0.053)\end{array}$ & -0.043 & $\begin{array}{c}-0.411 \\
(0.053)\end{array}$ & 0.495 \\
\hline$I K K \alpha$ & $\begin{array}{c}-0.164 \\
(0.054)\end{array}$ & $0.600^{*}$ & $\begin{array}{r}-0.380 \\
(0.052)\end{array}$ & -0.069 & $\begin{array}{c}-0.303 \\
(0.052)\end{array}$ & 0.099 & $\begin{array}{c}-0.283 \\
(0.054)\end{array}$ & 0.336 & $\begin{array}{r}-0.400 \\
(0.052)\end{array}$ & 0.002 & $\begin{array}{r}-0.420 \\
(0.054)\end{array}$ & 0.434 \\
\hline$R E L A$ & $\begin{array}{c}-0.252 \\
(0.066)\end{array}$ & $0.584^{*}$ & $\begin{array}{r}-0.356 \\
(0.064)\end{array}$ & $0.659^{*}$ & $\begin{array}{c}-0.209 \\
(0.063)\end{array}$ & 0.379 & $\begin{array}{c}-0.202 \\
(0.063)\end{array}$ & 0.337 & $\begin{array}{c}-0.325 \\
(0.061)\end{array}$ & $0.761^{* *}$ & $\begin{array}{c}-0.360 \\
(0.064)\end{array}$ & $0.605^{*}$ \\
\hline TRIAD3A & $\begin{array}{c}0.035 \\
(0.038)\end{array}$ & $0.554^{*}$ & $\begin{array}{c}-0.054 \\
(0.036)\end{array}$ & 0.462 & $\begin{array}{c}0.009 \\
(0.036)\end{array}$ & 0.107 & $\begin{array}{c}-0.063 \\
(0.038)\end{array}$ & $0.542^{*}$ & $\begin{array}{c}-0.231 \\
(0.036)\end{array}$ & -0.142 & $\begin{array}{r}-0.280 \\
(0.036)\end{array}$ & 0.492 \\
\hline РІЗК & $\begin{array}{c}-0.097 \\
(0.097)\end{array}$ & 0.563 & $\begin{array}{r}-0.756 \\
(0.088)\end{array}$ & $0.607^{*}$ & $\begin{array}{r}-0.767 \\
(0.081)\end{array}$ & $0.522^{*}$ & $\begin{array}{c}-0.597 \\
(0.088)\end{array}$ & 0.477 & $\begin{array}{c}-0.678 \\
(0.100)\end{array}$ & 0.119 & $\begin{array}{c}-0.919 \\
(0.085)\end{array}$ & $0.880^{* *}$ \\
\hline ATF3 & $\begin{array}{c}-0.620 \\
(0.055)\end{array}$ & $0.887^{* *}$ & $\begin{array}{c}-0.322 \\
(0.053)\end{array}$ & $0.689^{* *}$ & $\begin{array}{c}0.077 \\
(0.055)\end{array}$ & $0.608^{*}$ & $\begin{array}{c}0.315 \\
(0.053)\end{array}$ & $0.750^{* *}$ & $\begin{array}{c}0.171 \\
(0.053)\end{array}$ & 0.139 & $\begin{array}{c}0.060 \\
(0.053)\end{array}$ & 0.364 \\
\hline Il- 8 & $\begin{array}{c}-0.812 \\
(0.087)\end{array}$ & -0.516 & $\begin{array}{c}-0.260 \\
(0.075)\end{array}$ & 0.142 & $\begin{array}{c}0.205 \\
(0.075)\end{array}$ & 0.208 & $\begin{array}{c}0.356 \\
(0.075)\end{array}$ & $0.518^{*}$ & $\begin{array}{c}-0.102 \\
(0.075)\end{array}$ & -0.255 & $\begin{array}{c}-0.205 \\
(0.078)\end{array}$ & 0.164 \\
\hline$C 5 a R$ & $\begin{array}{c}-0.268 \\
(0.084)\end{array}$ & 1 & $\begin{array}{c}-0.448 \\
(0.080)\end{array}$ & 1 & $\begin{array}{c}-0.347 \\
(0.080)\end{array}$ & 1 & $\begin{array}{c}-0.302 \\
(0.080)\end{array}$ & 1 & $\begin{array}{c}-0.054 \\
(0.080)\end{array}$ & 1 & $\begin{array}{c}-0.152 \\
(0.080)\end{array}$ & 1 \\
\hline
\end{tabular}

₹ ${ }^{1}$ Minutes postincubation with a high concentration of C5a. Mean (SEM) represents mRNA expression of 3 cows.

$\stackrel{\cap}{\bar{D}}$. $\quad{ }^{2}$ Correlation coefficient between C5aR and TLR4 related genes.

గิ $* P<0.05 ; * * P<0.01$ (2-tailed). 


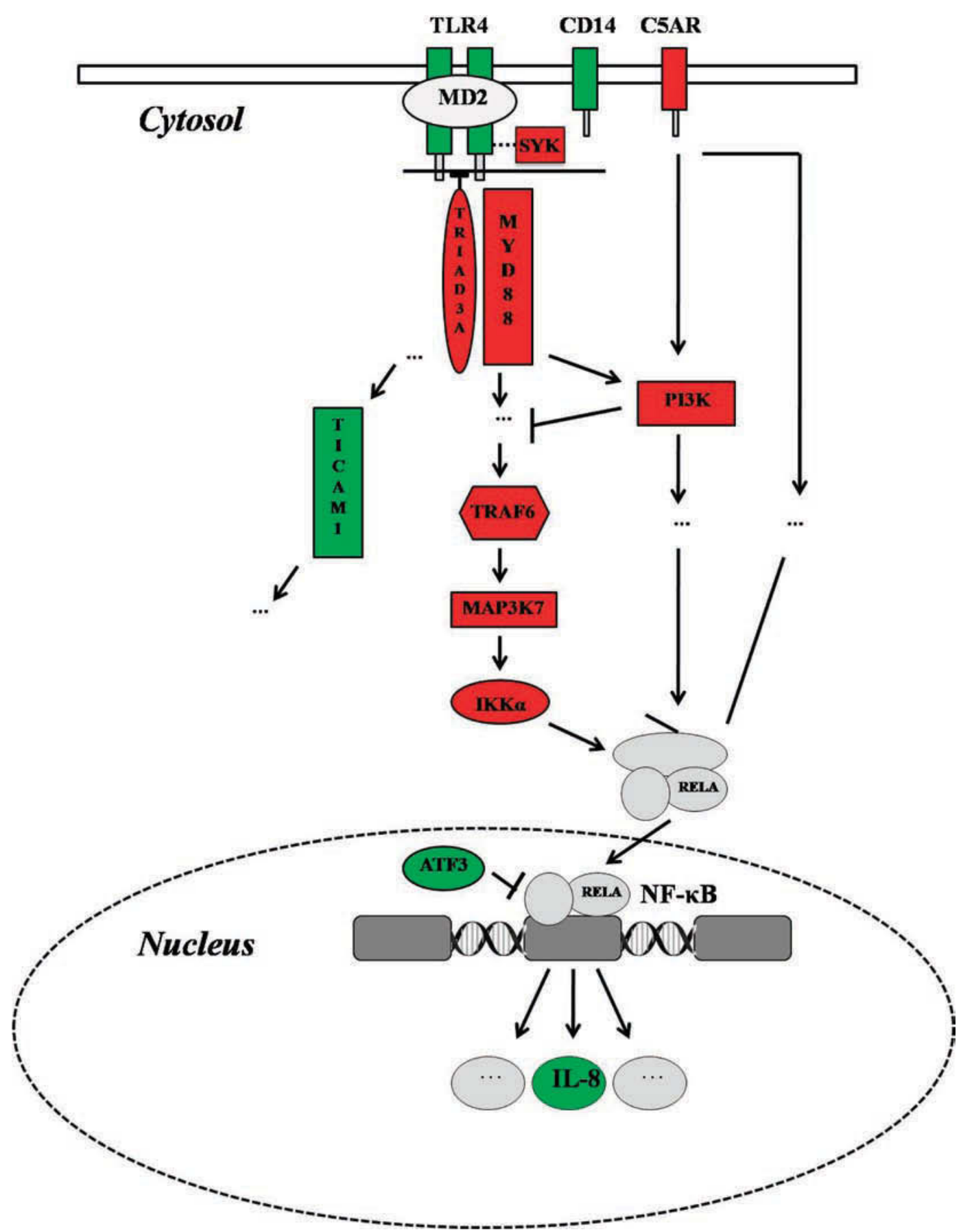

Figure 6. Overview of the effects of complement component 5a (C5a) on toll-like receptor 4 (TLR4) signaling. Our data show that mRNA transcripts for genes from the TLR4 signaling pathway increase (TRL4, CD14, TICAM1, ATF3, and IL-8; green), decrease (C5aR, PI3K, TRAF6, MAP3K7, Ikko; red), or remain unchanged (MD2 and RELA; gray). The TLR4 pathway is represented in a simplified scheme adapted from Lang and Mansell (2007). The dashed line denotes the association of spleen tyrosine kinase (Syk) with the TLR4 receptor. Dots represent genes that were left out to simplify the figure. Color version available in the online PDF.

during the onset of sepsis, when excessive concentrations of C5a are produced, blood neutrophils internalize their C5aR and subsequently reconstitute their C5aR content. These findings may explain the expression pattern of $C 5 a R$ mRNA that we observed in neutrophils after a C5a challenge. In addition, we studied the effect of C5a incubation on $I L-8$ expression levels over time, as several studies have shown that cytokine production in neutrophils can be induced by C5a (Bazzoni et al., 1991; Lord et al., 1991; Strieter et al., 1992). 
Hereby, we analyzed the mRNA levels of $I L-8$ based on the knowledge that an elevated cytokine production is usually preceded by, and largely dependent on, an accumulation of the corresponding mRNA transcripts (Bazzoni et al., 1991; Lord et al., 1991; Strieter et al., 1992). Our present results show that C5a is capable of activating the transcription of IL $8 \mathrm{mRNA}$ in bovine neutrophils within $40 \mathrm{~min}$. This is in agreement with a study of Hsu et al. (1999), where it was found that C5a induced the transcription of $I L 8$ in mononuclear cells and this induction was due to the activation of $N F-\kappa B$ (Hsu et al., 1999). It should be noted that the NF- $\kappa B$ complex in human mononuclear cells consists of different subunits compared with neutrophils (McDonald et al., 1997), and in contrast to mononuclear cells, C5a is an inhibitor of $N F-\kappa B$ activation in neutrophils (Guo and Ward, 2005). We did not observe an increase in $N F-\kappa B$ mRNA or a decrease in RELA transcripts upon C5a stimulation. Additionally, we found a clear increase in mRNA of the TLR $4 / C D 14$ receptor complex upon C5a incubation.

Cross-talk between the complement system and TLR has been shown in several studies. The LPS binding to CD14 induced upregulation of complement receptor 3 and initiated complex formation between both receptors on neutrophils (Weingarten et al., 1993; Zarewych et al., 1996). This CD14-complement receptor 3 interaction enhanced phagocytosis of mycobacteria (Sendide et al., 2005) and was a critical step for the uptake and killing of Salmonella (van Bruggen et al., 2007). The ability of C5a to upregulate CD14 expression in bovine neutrophils was similar to the upregulation observed in monocytes (Marchant et al., 1996). It has been demonstrated that $\mathrm{C} 5 \mathrm{a}$ is able to induce the release of IL-8 in human peripheral blood mononuclear cells without the requirement of a costimulatory factor such as LPS (Ember et al., 1994); also, human neutrophils seem capable of releasing IL-8 upon C5a stimulation, independent of costimulatory factors (Cassatella et al., 1992). The discovery of a second C5a receptor, called C5L2, could be a possible explanation. In resting human neutrophils, this receptor is localized in the granular structures in the neutrophils, whereas C5aR is located on the cell surface membrane (Bamberg et al., 2010). Upon C5a activation, the C5L2 receptor translocates to the cell surface and competes with the C5aR for the binding of C5a (Ward, 2009). However, the role of C5L2 in cytokine and chemokine production is still under debate (Ward, 2009). The C5aR/C5L2 system could be involved in the homeostatic response of bovine neutrophils to $\mathrm{C} 5 \mathrm{a}$ and, depending on their relative expression levels on the plasma membrane of the neutrophil upon C5a activation, an amplified or suppressed response could be generated.
Taken together, the results of the present study showed that the incubation of bovine neutrophils with a high concentration of $\mathrm{C} 5$ a resulted in time-dependent changes in the transcription of selected genes of the TLR4 pathway (Figure 6). Moreover, our data suggest the existence of cross-talk between the C5aR and TLR4 signaling pathways in these cells based on (1) the fact that C5aR could activate the TLR4/CD14 receptor complex and (2) the numerous correlations between C5aR and TLR4 pathway genes. Finally, a better understanding of interactions between C5a, C5aR, genes of the TLR4 pathway, and the activation of IL8 transcription could prove important for development of treatments for sepsis in dairy cows as C5a is extensively produced during sepsis and has been associated with dysfunction of neutrophils during sepsis.

\section{ACKNOWLEDGMENTS}

This study was financed by the Research FoundationFlanders (grant No. G.0050.06N).

\section{REFERENCES}

Akira, S., and K. Hoshino. 2003. Myeloid differentiation factor 88-dependent and independent pathways in toll-like receptor signaling. J. Infect. Dis. 187(Suppl. 2):S356-S363.

Bamberg, C. E., C. R. Mackay, H. Lee, D. Zahra, J. Jackson, Y. S. Lim, P. L. Whitfeld, S. Craig, E. Corsini, B. Lu, C. Gerard, and N. P. Gerard. 2010. The C5a receptor C5L2 is a negative modulator of C5aR mediated signal transduction. J. Biol. Chem. 285:7633-7644.

Bazzoni, F., M. A. Cassatella, C. Laudanna, and F. Rossi. 1991. Phagocytosis of opsonized yeast induces tumor necrosis factor-alpha mRNA accumulation and protein release by human polymorphonuclear leukocytes. J. Leukoc. Biol. 50:223-228.

Beutler, B., X. Du, and A. Poltorak. 2001. Identification of toll-like receptor 4 (TLR4) as the sole conduit for LPS signal transduction: Genetic and evolutionary studies. J. Endotoxin Res. 7:277-280.

Burvenich, C., V. Van Merris, J. Mehrzad, A. Diez-Fraile, and L. Duchateau. 2003. Severity of E. coli mastitis is mainly determined by cow factors. Vet. Res. 34:521-564.

Cassatella, M. A., F. Bazzoni, M. Ceska, I. Ferro, M. Baggiolini, and G. Berton. 1992. IL-8 production by human polymorphonuclear leukocytes. The chemoattractant formyl-methionyl-leucyl-phenylalanine induces the gene expression and release of IL- 8 through a pertussis toxin-sensitive pathway. J. Immunol. 148:3216-3220.

Chaudhary, A., T. M. Fresquez, and M. J. Naranjo. 2007. Tyrosine kinase Syk associates with toll-like receptor 4 and regulates signaling in human monocytic cells. Immunol. Cell Biol. 85:249-256.

Chen, L. F., S. A. Williams, Y. Mu, H. Nakano, J. M. Duerr, L. Buckbinder, and W. C. Greene. 2005. NF-kappaB RELA phosphorylation regulates RELA acetylation. Mol. Cell. Biol. 25:7966-7975.

Chuang, T. H., and R. J. Ulevitch. 2004. Triad3A, an E3 ubiquitinprotein ligase regulating toll-like receptors. Nat. Immunol. 5:495502.

De Ketelaere, A., K. Goossens, L. Peelman, and C. Burvenich. 2006. Validation of internal control genes for gene expression analysis in bovine polymorphonuclear leucocytes. J. Dairy Sci. 89:40664069 .

Ember, J. A., S. D. Sanderson, T. E. Hugli, and E. L. Morgan. 1994. Induction of interleukin-8 synthesis from monocytes by human C5a anaphylatoxin. Am. J. Pathol. 144:393-403. 
Fitzgerald, K. A., D. C. Rowe, and D. T. Golenbock. 2004. Endotoxin recognition and signal transduction by the TLR4/MD2-complex. Microbes Infect. 6:1361-1367.

Gennaro, R., T. Simonic, A. Negri, C. Mottola, C. Secchi, S. Ronchi, and D. Romeo. 1986. C5a fragment of bovine complement. Purification, bioassays, amino-acid sequence and other structural studies. Eur. J. Biochem. 155:77-86.

Gilchrist, M., V. Thorsson, B. Li, A. G. Rust, M. Korb, J. C. Roach, K. Kennedy, T. Hai, H. Bolouri, and A. Aderem. 2006. Systems biology approaches identify ATF3 as a negative regulator of tolllike receptor 4. Nature 441:173-178.

Goossens, K., M. Van Poucke, A. Van Soom, J. Vandesompele, A. Van Zeveren, and L. J. Peelman. 2005. Selection of reference genes for quantitative real-time $\mathrm{PCR}$ in bovine preimplantation embryos. BMC Dev. Biol. 5:27.

Guo, R. F., N. C. Riedemann, K. D. Bernacki, V. J. Sarma, I. J. Laudes, J. S. Reuben, E. M. Younkin, T. A. Neff, J. D. Paulauskis, F. S. Zetoune, and P. A. Ward. 2003. Neutrophil C5a receptor and the outcome in a rat model of sepsis. FASEB J. 17:1889-1891.

Guo, R. F., N. C. Riedemann, and P. A. Ward. 2004. Role of C5aC5aR interaction in sepsis. Shock 21:1-7.

Guo, R. F., and P. A. Ward. 2005. Role of C5a in inflammatory responses. Annu. Rev. Immunol. 23:821-852.

Hawlisch, H., Y. Belkaid, R. Baelder, D. Hildeman, C. Gerard, and J. Köhl. 2005. C5a negatively regulates toll-like receptor 4-induced immune responses. Immunity 22:415-426.

Hsu, M. H., M. Wang, D. D. Browning, N. Mukaida, and R. D. Ye. 1999. NF-kappaB activation is required for C5a-induced interleukin-8 gene expression in mononuclear cells. Blood 93:3241-3249.

Jack, R. S., X. Fan, M. Bernheiden, G. Rune, M. Ehlers, A. Weber, G. Kirsch, R. Mentel, B. Fürll, M. Freudenberg, G. Schmitz, F. Stelter, and C. Schütt. 1997. Lipopolysaccharide-binding protein is required to combat a murine gram-negative bacterial infection. Nature 389:742-745.

Lang, T., and A. Mansell. 2007. The negative regulation of Toll-like receptor and associated pathways. Immunol. Cell Biol. 85:425434

Lloyd, K. L., and P. Kubes. 2006. GPI-linked endothelial CD14 contributes to the detection of LPS. Am. J. Physiol. Heart Circ. Physiol. 291:H473-H481.

Lord, P. C., L. M. Wilmoth, S. B. Mizel, and C. E. McCall. 1991 Expression of interleukin-1 alpha and beta genes by human blood polymorphonuclear leukocytes. J. Clin. Invest. 87:1312-1321.

Marchant, A., C. Tielemans, C. Husson, K. Gastaldello, T. Schurmans, D. De Groote, J. Duchow, L. Vanherweghem, and M. Goldman. 1996. Cuprophane haemodialysis induces upregulation of LPS receptor (CD14) on monocytes: Role of complement activation. Nephrol. Dial. Transplant. 11:657-662.

McDonald, P. P., A. Bald, and M. A. Cassatella. 1997. Activation of the NF-kappaB pathway by inflammatory stimuli in human neutrophils. Blood 89:3421-3433.

Nemali, S., D. W. Siemsen, L. K. Nelson, P. L. Bunger, C. L. Faulkner, P. Rainard, K. A. Gauss, M. A. Jutila, and M. T. Quinn. 2008. Molecular analysis of the bovine anaphylatoxin C5a receptor. J. Leukoc. Biol. 84:537-549.

Pearl-Yafe, M., I. Fabian, D. Halperin, E. Flatau, S. Werber, and I. Shalit. 2007. Interferon-gamma and bacterial lipopolysaccharide act synergistically on human neutrophils enhancing interleukin-8, interleukin-1beta, tumor necrosis factor-alpha, and interleukin-12 p70 secretion and phagocytosis via upregulation of toll-like receptor 4. Shock 27:226-231.

Rainard, P. 2003. The complement in milk and defense of the bovine mammary gland against infections. Vet. Res. 34:647-670.
Riedemann, N. C., R. F. Guo, and P. A. Ward. 2003. A key role of C5a/C5aR activation for the development of sepsis. J. Leukoc. Biol. 74:966-970.

Sada, K., T. Takano, S. Yanagi, and H. Yamamura. 2001. Structure and function of Syk protein-tyrosine kinase. J. Biochem. 130:177186.

Sears, P. M., M. J. Paape, R. E. Pearson, and F. C. Gwazdauskas 1978. Comparison between tail vein and jugular vein cannulation in cattle. J. Dairy Sci. 61:974-979.

Sendide, K., N. E. Reiner, J. S. Lee, S. Bourgoin, A. Talal, and Z. Hmama. 2005. Cross-talk between CD14 and complement receptor 3 promotes phagocytosis of mycobacteria: Regulation by phosphatidylinositol 3-kinase and cytohesin-1. J. Immunol. 174:42104219

Shuster, D. E., M. E. Kehrli Jr., P. Rainard, and M. Paape. 1997 Complement fragment C5a and inflammatory cytokines in neutrophil recruitment during intramammary infection with Escherichia coli. Infect. Immun. 65:3286-3292.

Siemens, D. W., I. A. Schepetkin, L. N. Kirpotina, B. Lei, and M. T. Quinn. 2007. Neutrophil isolation from nonhuman species. Methods Mol. Biol. 138:21-34.

Stevens, M. G. H., L. Peelman, B. De Spiegeleer, A. Pezeshki, G. R. Van De Walle, L. Duchateau, and C. Burvenich. 2011. Differential gene expression of the TLR4 cascade and neutrophil function in early and mid-lactating dairy cows. J. Dairy Sci. doi:10.3168/ jds.2010-3563.

Strieter, R. M., K. Kasahara, R. M. Allen, T. J. Standiford, M. W. Rolfe, F. S. Becker, S. W. Chensue, and S. L. Kunkel. 1992. Cytokine-induced neutrophil-derived interleukin-8. Am. J. Pathol. 141:397-407.

Tak, P. P., and G. S. Firestein. 2001. NF-kappaB: A key role in inflammatory diseases. J. Clin. Invest. 107:7-11.

van Bruggen, R., D. Zweers, A. van Diepen, J. T. van Dissel, D. Roos, A. J. Verhoeven, and T. W. Kuijpers. 2007. Complement receptor 3 and Toll-like receptor 4 act sequentially in uptake and intracellular killing of unopsonized Salmonella enterica serovar Typhimurium by human neutrophils. Infect. Immun. 75:2655-2660.

Vandesompele, J., K. De Preter, F. Pattyn, B. Poppe, N. Van Roy, A. De Paepe, and F. Speleman. 2002. Accurate normalization of real-time quantitative RT-PCR data by geometric averaging of multiple internal control genes. Genome Biol. doi:10.1186/gb2002-3-7-research0034.

Ward, P. A. 2004. The dark side of C5a in sepsis. Nat. Rev. Immunol. 4:133-142.

Ward, P. A. 2009. Functions of C5a receptors. J. Mol. Med. 87:375378.

Weingarten, R., L. A. Sklar, J. C. Mathison, S. Omidi, T. Ainsworth, S. Simon, R. J. Ulevitch, and P. S. Tobias. 1993. Interactions of lipopolysaccharide with neutrophils in blood via CD14. J. Leukoc. Biol. 53:518-524.

Xia, Z. P., L. Sun, X. Chen, G. Pineda, X. Jiang, A. Adhikari, W. Zeng, and Z. J. Chen. 2009. Direct activation of protein kinases by unanchored polyubiquitin chains. Nature 461:114-119.

Zarewych, D. M., A. L. Kindzelskii, R. F. Todd III, and H. R. Petty 1996. LPS induces CD14 association with complement receptor type 3, which is reversed by neutrophil adhesion. J. Immunol. 156:430-433.

Zhong, H., R. E. Voll, and S. Ghosh. 1998. Phosphorylation of NFkappa B p65 by PKA stimulates transcriptional activity by promoting a novel bivalent interaction with the coactivator $\mathrm{CBP} /$ p300. Mol. Cell 1:661-671. 